\title{
Interesterification reaction activity, fatty acid composition and selectivity ratio of soybean oil
}

\author{
By Y. El-Shattory and Saadia M. Aly \\ Fats and Oils Department, National Research Centre, Dokki, Cairo, Egypt.
}

\section{RESUMEN}

Relación entre la actividad de la reacción de interesterificación, la composición en ácidos grasos y la selectividad en aceite de soja.

Se han llevado a cabo reacciones de interesterificación mediante la adición de ácido oleico a aceite de soja en la relación 1:2 w/w bajo diferentes condiciones de temperatura, agitación y porcentaje de catalizador.

La evaluación de la interesterificación de los aceites se realizó por determinación del índice de saponificación, el índice de iodo y la composición en ácidos grasos. Este estudio mostró que el ácido linolenico, que es responsable de la inestabilidad del flavor del aceite de soja y considerado como factor primario que contribuye a la deterioración de este aceite, podría ser reducido a cantidades menores o iguales al $3 \%$.

PALABRAS-CLAVE: Aceite de soja - Acido graso (composición en) - Acido oleico - Indice de iodo - Indice de saponificación - Interesterificación - Niquel.

\section{SUMMARY}

Interesterification reaction activity, fatty acid composition and selectivity ratio of soybean oil.

The interesterification reaction was carried out by adding oleic acid to soybean oil by ratio $1: 2 \mathrm{w} / \mathrm{w}$ under different conditions of temperature, stirring and catalyst percentages.

Assessment of the interesterification of oils was reported by determination of saponification value, iodine value and fatty acids composition. This study showed that linolenic acid which is responsible for flavour instability of soybean oil and consider as primary factor contributing to deterioration of this oil could be reduced to less than or equals $3 \%$.

KEY-WORDS: Fatty acid (composition) - Interesterification - lodine value - Nickel - Oleic acid - Saponification value Soybean oil.

\section{INTRODUCTION}

Interesterification of edible oils is an important process for the modification of physical and functional properties as are hydrogenation and fractionation (1). It is usually involves at least two oils that have different fatty acids composition (2). The classical interesterification is characterized by a randomization in the distribution of acyl moities in the triacylglycerol molecules by applying a chemical catalyst such as sodium alkoxide, sodium potassium alloy, metalic sodium and sodium hydroxide $(3,4)$. Interesterification is an old process whereby fats and olis can be randomized to improve plasticity, crystal habit or functional properties (5).

Chemical interesterification causes a statistical randomization of fatty acid distribution that leads to modification in triacylglycerols composition and, consequently, in physical behavior (6).

The increase in stability was attributed to a decrease in the amount of linolenic acid in soybean oil (7). The lack of frying stability and the poor frying oil performance of soybean and canola oils have been well documented $(8,9)$. Linolenic acid has been identified by various researchers as the primary factor contributing to deterioration of these oils during high-temperature use (10).

\section{MATERIALS AND METHODS}

Soybean oil and oleic acid were obtained from Cairo Company of Fats and Soap. The interesterification reaction carried out by adding oleic acid to soybean oil with ratio $1: 2 \mathrm{w} / \mathrm{w}$ and $0.2 \%$ Nickel catalyst at $60^{\circ} \mathrm{C}$ with stirring for 2 hours in oil bath. The experiment was repeated for 4 and 6 hours respectively, under the same conditions of temperature and catalyst percentage. The experiment was re-done at temperatures of 90 and $120^{\circ} \mathrm{C}$ under same conditions of catalyst percentage, temperature and stirring times reported before. The experiment giving the optimum results was repeated with $0.4 \%$ and $0.6 \%$ Nickel catalyst at $90^{\circ} \mathrm{C}$ with stirring for 4 hours.

The saponification value (S.V) and iodine value (I.V) of interesterified oil were determined by method described in AOCS $(11,12)$.

Analysis of fatty acids was done by gas liquid chromatography (13) using Varian 3700 and flame ionization detector where the conditions are:

- Column package $20 \%$ diethylene glycol succinate (DEGS) on chromosorb W (60 - 80 mesh) column length 6 feet with internal diameter of 0.25 inch. 
- Column temperature for fatty acids is isothermal at $195^{\circ} \mathrm{C}$. Injection temperature is $220^{\circ} \mathrm{C}$ but detector temperature is $300^{\circ} \mathrm{C}$.

- Carrier gas $(\mathrm{He})$ flow rate is $30 \mathrm{ml} / \mathrm{min}$ and hydrogen flow rate is $30 \mathrm{ml} / \mathrm{min}$ also, but air flow rate is $300 \mathrm{ml} / \mathrm{min}$.

\section{RESULTS AND DISCUSSION}

Concerning this study, the chemical characteristics of interesterified soy oil such as iodine and saponification values are registered in tables I and II. Table I shows the results of chemical characteristics of interesterification process at 60,90 and $120^{\circ} \mathrm{C}$ for 2,4 and 6 hours of stirring using $0.2 \%$ Nickel catalyst. On the other hand table II reports the chemical characteristics of soy oil which was interesterified at $90^{\circ} \mathrm{C}$ for 4 hours of stirring using 0.4 and $0.6 \%$ Nickel catalyst. Since iodine value reached a low comparable with that of soy oil before carring out interesterification process (control) while saponification values moved just a little after interesterification.

Table I

Chemical characteristic of interesterified soy oil at different temperature and time of stirring using $0.2 \%$ Nickel catalyst.

\begin{tabular}{rrrrrrr}
\hline $\begin{array}{c}\text { Heating } \\
\text { temp. }\end{array}$ & \multicolumn{2}{c}{2 hours stirring } & \multicolumn{2}{c}{4 hours stirring } & \multicolumn{2}{c}{6 hours stirring } \\
& I.V. & S.V. & I.V. & S.V. & I.V. & S.V. \\
\hline $60^{\circ} \mathrm{C}$ & 117.1 & 194.8 & 117.8 & 195.5 & 117.3 & 200.3 \\
$90^{\circ} \mathrm{C}$ & 110.3 & 195.6 & 110.7 & 196.8 & 114.1 & 202.5 \\
$120^{\circ} \mathrm{C}$ & 110.3 & 196.8 & 109.5 & 202.6 & 110.1 & 202.9 \\
\hline
\end{tabular}

* lodine value of soybean oil (control) was 125.8

** Saponification value of soybean oil (control) was 196.8 .

Table II

Chemical characteristic of interesterified soy oil at $90^{\circ} \mathrm{C}$ and 4 hours stirring using 0.4 and 0.6 Nickel catalyst

\begin{tabular}{ccc}
\hline$\%$ of catalyst & I.V. & S.V. \\
\hline $0.4 \%$ & 112.0 & 207.2 \\
$0.6 \%$ & 115.3 & 202.5 \\
\hline
\end{tabular}

The iodine number represents true unsaturation of fats and fatty acids only when the double bonds are unconjugated and the structure is not severely hindered, i.e during interesterification process some of the double bonds going to be broken and iodine value moves to a low level. An interesterification at $90^{\circ} \mathrm{C}$ for two hours using $0.2 \%$ of nickel catalyst was markedly more active where activity of interesterification process equals droping in iodine value/time. Interesterification reaction using $0.2 \%$ of nickel catalyst at the other temperatures and times of stirring had activity in the range of 1.43 4.08 table III whereas the activity of interesterification process using 0.4 and $0.6 \%$ of nickel catalyst at $90^{\circ} \mathrm{C}$ for 4 hours stirring were 3.45 and 2.57 respectively. We may trace that iodine values of the interesterified soy oil met linoleic and linolenic acid percentages. Also decreasing or increasing percentages of fatty acids are proportional to their molecular weights and the total molecular weights of individual fatty acids related to saponification value of the oil.

Table III

Activity of interesterification reaction by using $0.2 \%$ Nickel

\begin{tabular}{ccccccc}
\hline \multirow{2}{*}{ Heating } & \multicolumn{2}{c}{2 hours } & \multicolumn{2}{c}{4 hours } & \multicolumn{2}{c}{6 hours } \\
& $\Delta l . V$. & $\Delta l . V / t i m e$ & $\Delta l . V$. & $\Delta l . V /$ time & $\Delta l . V$. & $\Delta l . V / t i m e$ \\
\hline 0 & & - & - & - & - & - \\
$60^{\circ} \mathrm{C}$ & 8.7 & 4.35 & 8.0 & 2.0 & 8.5 & 1.42 \\
$90^{\circ} \mathrm{C}$ & 14.7 & 7.35 & 15.1 & 3.78 & 11.7 & 1.95 \\
$120^{\circ} \mathrm{C}$ & 14.7 & 7.35 & 16.3 & 4.07 & 15.7 & 2.62 \\
\hline
\end{tabular}

Where IV = Droping in iodine value

IV/time = Activity of interesterification process.

Tables IV-VII shows fatty acids composition of soy oil after doing interesterification process at different temperature and several times of stirring using various percentages of nickel catalyst comparable with that of soy oil before interesterification process. The results appear decreasing of linoleic and linolenic acids while increasing of oleic and stearic acids percentages.

From the changes in fatty acids composition during interesterification, the selectivity ratio (SR) was calculated using Allen's method (14) as original proposed by Albright (15).

[SR is defined as $K_{2} / K_{3}$, where $K_{2}=1-L_{0}, K_{3}=S-S_{0}$ $\left(L_{0}\right.$ and $\left.S_{0}\right)$ represent the linoleic and stearic acid contents in the original oil (control) and $L$ and $S$ in the interesterified sample (table VIII). In the same manner the selectivity ratio (SR) regarding linolenic acid would be calculated and recorded in table IX. The highest values of selectivity ratio of interesterification reaction are 0.08 and 0.04 for linoleic and linolenic acid concerning the reaction using $0.2 \%$ nickel catalyst at $60^{\circ} \mathrm{C}$ for 2 hours of stirring. The selectivity ratio during interesterification reaction using 0.4 and $0.6 \%$ of nickel catalyst at $90^{\circ} \mathrm{C}$ for 4 hours stirring were 0.03 and 0.03 respectively for linoleic acid and 0.03 and 0.02 respectively for linolenic acid. 
Table IV

Fatty acid composition of interesterified soy oil at $60^{\circ} \mathrm{C}$ using $0.2 \%$ Nickel catalyst

\begin{tabular}{rrrcc}
\hline Fatty acid & control & 2 hours stirring & 4 hours stirring & 6 hours stirring \\
\hline$c_{16: 0}$ & 15.0 & 9.62 & 10.02 & 9.60 \\
$c_{18: 0}$ & 9.2 & 12.89 & 18.13 & 26.20 \\
$c_{18: 1}$ & 20.8 & 36.77 & 31.29 & 24.30 \\
$c_{18: 2}$ & 48.4 & 34.53 & 33.52 & 33.0 \\
$c_{18: 3}$ & 7.2 & 6.20 & 6.98 & 6.60 \\
\hline
\end{tabular}

Table V

Fatty acid composition of interesterified soy oil at $90^{\circ} \mathrm{C}$ using $0.2 \%$ Nickel catalyst

\begin{tabular}{crccc}
\hline Fatty acid & control & 2 hours stirring & 4 hours stirring & 6 hours stirring \\
\hline$c_{16: 0}$ & 15.0 & 9.52 & 9.73 & 10.22 \\
$c_{18: 0}$ & 9.2 & 18.13 & 12.96 & 29.75 \\
$c_{18: 1}$ & 20.8 & 28.30 & 35.66 & 22.16 \\
$c_{18: 2}$ & 48.4 & 37.58 & 35.76 & 30.97 \\
$c_{18: 3}$ & 7.2 & 6.48 & 5.87 & 6.88 \\
\hline
\end{tabular}

Table VI

Fatty acid composition of interesterified soy oil at $120^{\circ} \mathrm{C}$ using $0.2 \%$ Nickel catalyst

\begin{tabular}{ccccc}
\hline Fatty acid & control & 2 hours stirring & 4 hours stirring & 6 hours stirring \\
\hline$c_{16: 0}$ & 15.0 & 10.24 & 9.72 & 10.10 \\
$c_{18: 0}$ & 9.2 & 18.86 & 16.68 & 26.72 \\
$c_{18: 1}$ & 20.8 & 31.54 & 31.89 & 25.30 \\
$c_{18: 2}$ & 48.4 & 33.27 & 35.15 & 31.20 \\
$c_{18: 3}$ & 7.2 & 6.10 & 6.50 & 6.60 \\
\hline
\end{tabular}

Table VII

Fatty acid composition of interesterified soy oil at $90^{\circ} \mathrm{C}$ and 4 hours stirring using 0.4 and $0.6 \%$ Nickel catalyst

\begin{tabular}{cccc}
\hline Fatty acid & control & $0.4 \% \mathrm{Ni}$ & $0.6 \% \mathrm{Ni}$ \\
\hline${ }^{c_{16: 0}}$ & 15.0 & 10.70 & 12.0 \\
$\mathrm{c}_{18: 0}$ & 9.2 & 38.40 & 39.60 \\
$\mathrm{c}_{18: 1}$ & 20.8 & 43.30 & 39.20 \\
${ }_{18}{ }_{18: 2}$ & 48.4 & 6.11 & 5.30 \\
$c_{18: 3}$ & 7.2 & 1.11 & 3.90 \\
\hline
\end{tabular}

Table VIII

Selectivity ratio of linoleic acid during interesterification reaction using $0.2 \%$ nickel catalyst.

\begin{tabular}{ccccccccccc}
\hline $\begin{array}{c}\text { Time of } \\
\text { stirring }\end{array}$ & S-So & L/L & $\begin{array}{c}60^{\circ} \mathrm{C} \\
\text { Selectivity } \\
\text { ratio }\end{array}$ & S-So & L/L & $\begin{array}{c}\text { Selectivity } \\
\text { ratio }\end{array}$ & S-S & LLo & $\begin{array}{c}\text { Selectivity } \\
\text { ratio }\end{array}$ \\
\hline 2 & 3.69 & 0.71 & 0.08 & 8.93 & 0.77 & 0.03 & 9.66 & 0.68 & 0.033 \\
4 & 8.93 & 0.69 & 0.03 & 3.76 & 0.74 & 0.07 & 7.48 & 0.72 & 0.037 \\
6 & 17.0 & 0.68 & 0.018 & 20.55 & 0.64 & 0.017 & 17.52 & 0.64 & 0.02 \\
\hline
\end{tabular}

Table IX

Selectivity ratio of linolenic acid during interesterification reaction using $0.2 \%$ nickel catalyst.

\begin{tabular}{cccccccccc}
\hline $\begin{array}{c}\text { Time of } \\
\text { stirring }\end{array}$ & S-S & Ln/Lo & $\begin{array}{c}60^{\circ} \mathrm{C} \\
\text { Selectivity } \\
\text { ratio }\end{array}$ & S-S & Ln/Lo & $\begin{array}{c}\text { Selectivity } \\
\text { ratio }\end{array}$ & S-S & Ln/Lo & $\begin{array}{c}\text { Selectivity } \\
\text { ratio }\end{array}$ \\
\hline 2 & 3.69 & 0.861 & 0.04 & 8.93 & 0.9 & 0.011 & 9.66 & 0.85 & 0.02 \\
4 & 8.93 & 0.96 & 0.004 & 3.76 & 0.82 & 0.05 & 7.48 & 0.90 & 0.013 \\
6 & 17.0 & 0.92 & 0.005 & 20.55 & 0.96 & 0.001 & 17.52 & 0.92 & 0.005 \\
\hline
\end{tabular}

Figures 1-5 show some relations of data derived from the results of this study. 


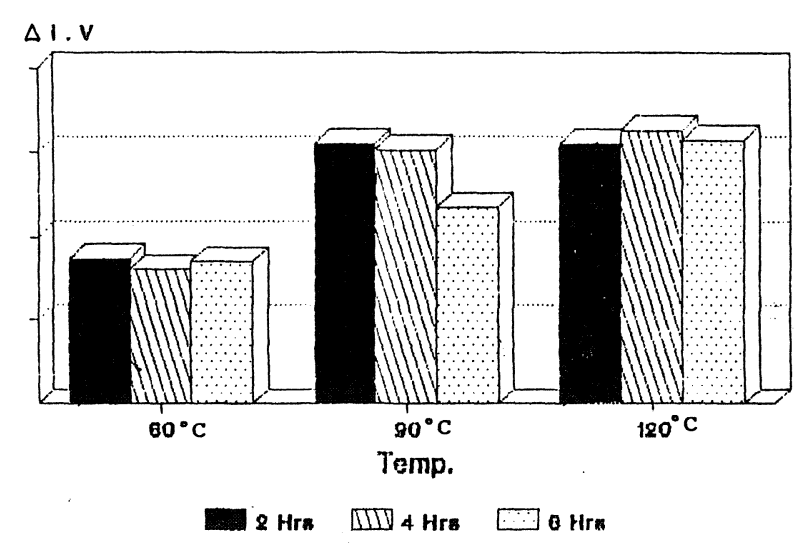

Figure 1

Relation between temperature and dropping in iodine value for 2,4 and 6 hrs using $0.2 \%$ nickel catalyst



Figure 2

Relation between dropping in iodine value and dropping in linoleic and linolenic acids using $0.2 \%$ nickel catalyst



Figure 3

Relation between fatty acid percentages and their corresponding molecular weights for interesterified at $60^{\circ} \mathrm{C}$ using $0.2 \%$ nickel catalyst

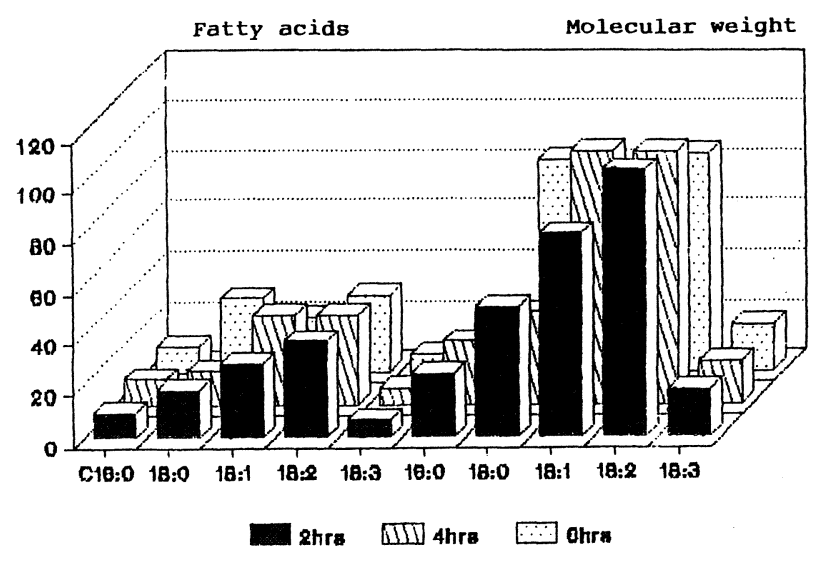

Figure 4

Relation between fatty acid percentages and their corresponding molecular weights for interesterified soybean oil at $90^{\circ} \mathrm{C}$ using $0.2 \%$ nickel catalyst

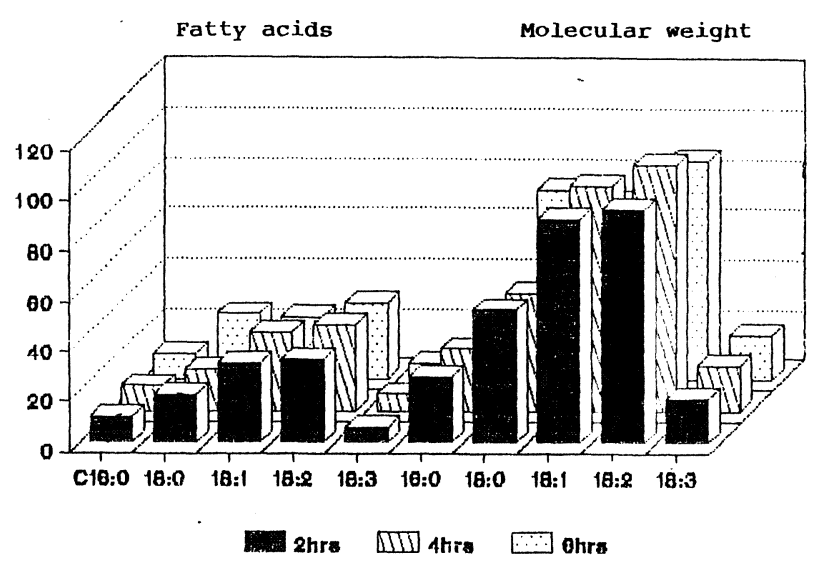

Figure 5

Relation between fatty acid percentages and their corresponding molecular weights for interesterified soybean oil at $120^{\circ} \mathrm{C}$ using $0.2 \%$ nickel catalyst

\section{REFERENCES}

1. Konishi, H., Neff, W.E. y Mounts, T.L. (1995).——Oxidative stability of soybean oil products obtained by regioselective chemical interesterification".- Journal of the American Oil Chemists'Society 72 (11) 1393-1398.

2. Konishi, H., Neff, W.E. y Mounts, T.L. (1993)."Chemical interesterification with regioselectivity for edible oils".-Journal of the American Oil Chemists' Society 70 (94) 411-415.

3. Sonntag, N.O.V.-In Bailey's Industrial Oil and Fat Products. Vol. II, 4th edn. Edited by D. Swern, John Wiley and Sons. New York, p. 153, 1982.

4. Sreenivasan, B. (1978).- - «Interesterification of fats".- Journal of the American Oil Chemists'Society 55, 796-805.

5. List, G.R., Mounts, T.L., Orthoefer, F. y Neff, W.E. (1995).— - Margarine and shortening oils by interesterification of liquid and trisaturated triglycerides". Journal of the American Oil Chemists'Society 72 (3) 379-382. 
6. Rousseau, D., Forestiere, K., Hill, A.R. y Marangoni, A.G. (1996)._ «Restructuring butterfat through blending and chemical interesterification. I. Melting behavior and triacylglycerol modifications".- Journal of the American Oil Chemists'Society 73 (8) 963-971.

7. Miller, L.A. y White, P.J. (1988).— «High temperature stabilities of low-linolenate, high-stearate and common soybean oils".- Journal of the American Oil Chemists'Society 65 (8) 1324-1327.

8. Stevenson, S.G., Vaisey-Genser, M. y Eskin, N.A.M. (1984). - «Quality control in the use of deep frying oils".-Journal of the American Oil Chemists'Society 61 (6) 1102-1108.

9. Frankel, E.N., Warner, K. y Moulton SR, K.J. (1985).«Effects of hidrogenation and additives on cooking oil perfommance of soybean oil».- Journal of the American Oil Chemists'Society 62, 1354.

10. Warner, K. y Mounts, T.L. (1993).— «Frying stability of soybean and canola oils with modified fatty acid compositions".-Journal of the American Oil Chemists'Society 70 (10) 983-988.
11. Official and Tentative Methods of the American Oil ChemistsSociety, $3^{\text {rd }}$ edn. (1993) AOCS, Chicago, Illinois.

12. Official and Tentative Methods of the American Oil ChemistsSociety, $3^{\text {rd }}$ edn. (1995).

13. Ludde, F.E., Barvord, R.A. y Reimenschnider, R.W. (1960). - «Direct conversion of lipid components to their fatty acid methyl ester".- - Journal of the American Oil Chemists'Society 37, 447-451.

14. Allen, R.R. (1978)._- «Principles and catalysts for hydrogenation of fats and oils".- Journal of the American Oil Chemists'Society 55 (11) 792-795.

15. Albright, L.F. (1965)._- «Quantitative measure of selectivity of hydrogenation of triglycerides".- Journal of the American Oil Chemists'Society 42 (3) 250-253.

Recibido: Agosto 1997 Aceptado: Febrero 1998 